\title{
Quantitative determination of ciprofloxacin and norfloxacin in pharmaceutical preparations by high performance liquid chromatography
}

\author{
Nájla Mohamad Kassab, Anil Kumar Singh, Erika Rosa Maria Kedor-Hackmam, \\ Maria Inês Rocha Miritello Santoro* \\ Departamento de Farmácia, Faculdade de Ciências Farmacêuticas, Universidade de São Paulo
}

*Correspondence:

M. I. R. M. Santoro

Departamento de Farmácia,

Faculdade de Ciências Farmacêuticas,

Universidade de São Paulo,

CP 66083, CEP 05315-970, São Paulo,

Brasil

E-mail: ines@usp.br
The objective of this research was to develop and validate an analytical method for quantitative determination of ciprofloxacin (CIP) and norfloxacin (NOR) in pharmaceutical preparations. A simple and rapid chromatographic method was developed and validated for quantitative determination of two fluoroquinolone antibiotics in tablets and injection preparations. The quinolones were analyzed by using a LiChrospher ${ }^{\circledR} 100$ RP-18 column (5 $\mu \mathrm{m}, 125 \times 4 \mathrm{~mm}$ ) and a mobile phase consisted of water:acetonitrile:triethylamine (80:20:0.3 v/v/v). The $\mathrm{pH}$ of final mixture was adjusted to 3.3 with phosphoric acid. The flow rate was $1.0 \mathrm{~mL} / \mathrm{min}$ and $U V$ detection was made at $279 \mathrm{~nm}$. The analyses were performed at room temperature $\left(24 \pm 2{ }^{\circ} \mathrm{C}\right)$. CIP and NOR were eluted within $5 \mathrm{~min}$. The calibration curves were linear ( $r>0.9999)$ over a concentration range from 4.0 to 24.0 $\mu \mathrm{g} / \mathrm{mL}$. The relative standard deviation (RSD) was $<1.0 \%$ and the mean recovery was $101.85 \%$.

\section{INTRODUCTION}

Fluoroquinolones comprise a series of broadspectrum synthetic antibacterial agents derived from nalidixic acid. They were discovered casually in 1962 and since then are essentially used in the treatment of several infectious diseases (Bertino and Fish, 2000; Fierens, Hillaert and Van Den Bossche, 2000; Marzo and Dal Bo, 2002; Arteseros et al., 2002).

Ciprofloxacin (CIP) and norfloxacin (NOR) are quinolones with fluorine at position 6 of naphthyridine ring. The chemical structures of fluoroquinolones are shown in Figure 1. Published structure-activity data shows that fluorine atom help broadens their activity spectrum against both gram-negative and gram-positive pathogens (Lorian,
1996; Bertino, Fish, 2000; Fierens, Hillaert and Van Den Bossche, 2000; Arteseros et al., 2002; Samanidou, Demetriou, Papadoyannis, 2003).

The primary target of fluoroquinolones is bacterial enzyme DNA gyrase or topoisomerase II (Mandel, Petri Júnior, 1996; Bertino, Fish, 2000; Marzo, Dal Bo, 2000; Arteseros et al., 2002). They are generally well tolerated, safe and adverse effects vary significantly depending on their physicochemical properties (Mandel, Petri Júnior, 1996; Bertino, Fish, 2000). Majority of them are well absorbed through oral route and have a long half-life, being widely distributed within body tissues and fluids (Marzo, Dal Bo, 2002; Samanidou, Demetriou, Papadoyannis, 2003).

Due to the minor structural differences amongst members of the same group, it is difficult to identify and to 
<smiles>O=C(O)c1cn(C2CC2)c2cc(N3CCNCC3)c(F)cc2c1=O</smiles>

Ciprofloxacin

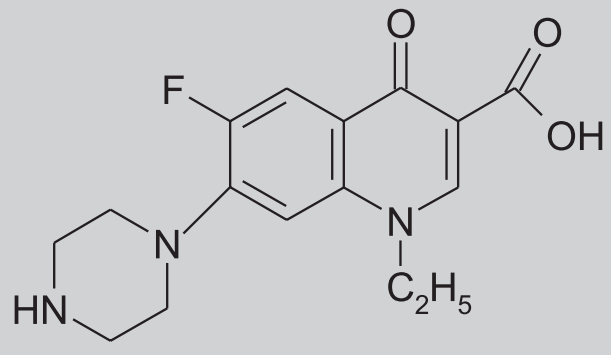

Norfloxacin

FIGURE 1. Chemical structures of ciprofloxacin and norfloxacin.

determine their respective degradation products (Joshi, 2002). Several analytical methods for quantitative determination of fluoroquinolones in pharmaceutical formulations are described in scientific literature, like capillary electrophoresis (Bhowal, Das, 1991; Flurer, 1997; Sun, Chen, 1997), UV spectrophotometry (Fratini, Schapoval, 1996; Chowdary, Rao, 1997), titrimetry (Belal, Al-Majed, Al-Obaid, 1999), and high performance liquid chromatography (HPLC) (United States Pharmacopeia , 2004; British Pharmacopoeia, 1999; Mazuel, 1991), amongst others.

HPLC is widely employed for the determination of CIP and NOR either in biological fluids, edible animal products, feed and pharmaceutical formulations (Barbosa, Berges, Sanz-Nebot, 1996; Belal, Al-Majed, Al-Obaid, 1999; Budvari-Barany et al. 1991; Córdoba-Borrego, Cordoba-Diaz, Cordoba-Diaz, 1999; Husain et al. 1995; Kirkland, Mccombs, Kirkland, 1994; Lacroix, Curran, Sears, 1996; Morley, Erold, 1993; Samanidou, Christodoulou, Papadoyannis, 2005; Sowinski, Kays, 2004; Thoppil, Amin, 2000; Tiefenbacher et al. 1994; Torniainen, Tammilehto, Ulvi, 1996; Vybiralova et al. 2005).

Majority of these HPLC methods were applied in determination of fluoroquinolones in biological fluids, edible animal products, feeds and to a lesser extent in pharmaceutical formulations. Most of the reported methods involve troublesome mobile phase (buffers) and difficult sample preparation. The objective of this research was to develop and validate an efficient HPLC method for quantitative determination of second-generation quinolones in pharmaceutical preparations. A rapid, accurate and sensitivity method was developed for quantitative determination of two fluoroquinolones: CIP and NOR in tablets and injectable preparations.

\section{EXPERIMENTAL}

\section{Material}

\section{Reagents and chemicals}

All solvents were of HPLC grade and reagents were analytical grade. Acetonitrile and phosphoric acid were obtained from Merck ${ }^{\circledR}$. Analytical grade triethylamine was purchased from Sigma ${ }^{\circledR}$. Water was purified with Milli-Q ${ }^{\circledR}$ Plus, Millipore System. All solvents and solutions were filtered through membrane filter (Millipore Millex $^{\circledR}$ - HV filter units, Durapore - PVDF, polyethylene, $0.45 \mu \mathrm{m}$ pore size) and degassed before use.

The active pharmaceutical ingredients (API) including CIP (99.5\%) and NOR (100.1\%) were kindly donated by a local pharmaceutical industries and were used as reference standards without further purification.

\section{Samples}

The samples used in this research are presented in Table 1.

TABLE I - Commercial pharmaceutical dosage form samples of ciprofloxacin and norfloxacin used in the research

\begin{tabular}{cccc}
\hline $\begin{array}{c}\text { Sample } \\
\text { number }\end{array}$ & $\begin{array}{c}\text { Pharmaceutical } \\
\text { industries }\end{array}$ & Drug & $\begin{array}{c}\text { Pharmaceutical } \\
\text { dosage form }\end{array}$ \\
\hline 1 & A & $\begin{array}{c}\text { Ciprofloxacin } \\
\text { hydrochloride } \\
\text { Ciprofloxacin } \\
\text { hydrochloride }\end{array}$ & $\begin{array}{c}\text { Tablets } \\
(250 \mathrm{mg}) \\
\text { Tablets } \\
(500 \mathrm{mg})\end{array}$ \\
3 & B & Ciprofloxacin & Injection $100 \mathrm{~mL}$ \\
(freebase) & $(20 \mathrm{mg} / \mathrm{mL})$ \\
4 & D & $\begin{array}{c}\text { Norfloxacin } \\
\text { (freebase) }\end{array}$ & $\begin{array}{c}\text { Tablets } \\
(400 \mathrm{mg})\end{array}$ \\
5 & E & $\begin{array}{c}\text { Norfloxacin } \\
\text { (freebase) }\end{array}$ & $\begin{array}{c}\text { Tablets } \\
(400 \mathrm{mg})\end{array}$ \\
\hline
\end{tabular}

(a) Pharmaceutical industries are identified by letters and samples by numbers 


\section{Instrumentation}

\section{A. HPLC System}

High performance liquid chromatographic system model Varian ${ }^{\circledR} 5000$, equipped with injection valve Rheodyne $^{\circledR}$ model 7125 with $20 \mu \mathrm{L}$ fixed loop, variable ultraviolet detector Varian ${ }^{\circledR}$ model 4000 and integrator Varian ${ }^{\circledR}$ model 4400.

\section{B. Column}

The analytical column was a reversed phase LiChrospher ${ }^{\circledR} 100 \mathrm{RP}-18(125 \times 4 \mathrm{~mm}, 5 \mu \mathrm{m})$ in LichroCART $^{\circledR}-$ Merck.

\section{Methods}

\section{Chromatographic conditions}

All analyses were done at ambient temperature $\left(24 \pm 2{ }^{\circ} \mathrm{C}\right)$ under isocratic conditions. The mobile phase consisted of a volumetric mixture of water:acetonitrile:triethylamine $(80: 20: 0.3 \mathrm{v} / \mathrm{v} / \mathrm{v})$. The $\mathrm{pH}$ of final mixture was adjusted to 3.3 with phosphoric acid. The flow rate was $1.0 \mathrm{~mL} / \mathrm{min}$ and volume of injection was $20 \mu \mathrm{L}$. All solutions, including mobile phase, were sonicated during $25 \mathrm{~min}$ before use. The UV detection was made at $279 \mathrm{~nm}$.

\section{Standard solutions preparation}

Accurately weighed amount of standards of CIP and NOR, equivalent to $20.0 \mathrm{mg}$ of freebase were transferred to $100 \mathrm{~mL}$ volumetric flasks, separately. The volume was completed with mobile phase and methanol, in case of CIP and NOR, respectively. The resulting solutions were sonicated during $25 \mathrm{~min}$ and filtered through a filtration membrane. Final concentrations were $200.0 \mu \mathrm{g} / \mathrm{mL}$. Aliquots of each solution were accordingly diluted with mobile phase in order to obtain solutions with final concentration of $50.0 \mu \mathrm{g} / \mathrm{mL}$.

\section{Calibration curves}

Six different concentration levels $(4.0,8.0,12.0,16.0$, 20.0 and $24.0 \mu \mathrm{g} / \mathrm{mL}$ ) were obtained of each standard solution, conveniently diluted with mobile phase. Each solution was injected in the chromatographic system $(\mathrm{n}=3)$ and mean values of peak areas were plotted against concentrations. The curves were adjusted by linear regression with least mean square method (Harris, 2001; Leite, 2002).

\section{Linearity}

The linearity of the proposed method was evaluated by using calibration curves to calculate coefficient of correlation and intercept values.

\section{Sample preparation}

\section{Tablets}

Twenty tablets of each sample were individually weighed and triturated to obtain homogeneous mixture. An amount of powder equivalent to $100.0 \mathrm{mg}$ of freebase, was transferred to a $100 \mathrm{~mL}$ volumetric flask. The volume was completed with mobile phase for CIP, while for NOR, methanol was used. The resulting solutions were sonicated during $25 \mathrm{~min}$ to facilitate proper solubilization. All the solutions were filtered through Whatman filter paper $\mathrm{n}^{\circ} 1$ Aliquots of each filtered solution were accordingly diluted, with mobile phase, in order to obtain solutions with final concentration of $50.0 \mu \mathrm{g} / \mathrm{mL}$. Assays were performed after appropriate dilutions of above solution.

\section{Injectable preparations}

For injectable sample, $5.0 \mathrm{~mL}$ of the solution was accurately measured and the procedure adopted for sample preparation was similar to that described for tablets. Appropriate dilutions were made with mobile phase to final solutions containing $50.0 \mu \mathrm{g} / \mathrm{mL}$ of the drug in freebase. Assays were performed after appropriate dilutions of above solution.

\section{Specificity}

The specificity of proposed method was evaluated by comparing the results obtained by analysis of placebo formulations using the proposed method.

\section{Accuracy}

To evaluate the accuracy of the proposed method, recovery tests were carried out with all samples. Recovery tests were performed by adding known amounts of standard solutions to sample followed by analysis using the proposed method. Aliquots of standard and samples solutions were transferred to $25 \mathrm{~mL}$ volumetric flasks and final volumes were completed with mobile phase. The percentage of recovery $(\mathrm{R} \%)$ was calculated as indicated by Association of Official Analytical Chemists International (2002).

\section{Precision}

The precision of proposed method was evaluated through intra-day repeatability of responses after replicate $(\mathrm{n}=10)$ injection of sample solutions $(5.0 \mu \mathrm{g} / \mathrm{mL})$. The precision is expressed as RSD amongst responses. 


\section{Robustness}

The robustness of the proposed method was evaluated by intentional minor modifications in the composition of the mobile phase as well as its $\mathrm{pH}$. The modified mobile phase was used to analyze drug samples (Chromatograms not shown).

\section{Detection limit (DL) and quantification limit (QL)} equations:

The DL and QL were calculated through following

$D L=\frac{S D}{\alpha} \times 3$

(Equation 1)

$Q L=\frac{S D}{\alpha} \times 10$

(Equation 2)

Where:

$\mathrm{SD}=$ Standard deviation of curve,

$\alpha=$ Slope of curve

\section{RESULTS AND DISCUSSION}

In order to validate an efficient method for analysis of drugs in pharmaceutical formulations, preliminary tests were performed with the objective to select adequate and optimum conditions. Parameters such as detection wavelength, ideal mobile phase and their proportions, optimum $\mathrm{pH}$ and concentration of the standard solutions were exhaustively studied.

Several binary or ternary eluents were tested using different proportions of solvents such as acetonitrile, methanol and water. Some ion-pair reagents were also studied. A flow rate of $1.0 \mathrm{~mL} / \mathrm{min}$ was selected after preliminary tests.

The proposed method is simple and do not involve laborious time-consuming sample preparation. The method was statistically validated for their accuracy and precision. The chromatograms of sample containing CIP and NOR can be observed in Figure $2(\mathrm{a}-\mathrm{b})$ and $2 \mathrm{c}$, respectively. As could be seen, excipients did not interfere in the analysis of CIP and NOR using proposed method.

The calibration curves showed linearity over a concentration range from 4.0 to $24.0 \mu \mathrm{g} / \mathrm{mL}$. The correlation coefficients obtain with linear regression of curve were better than 0.9999 . Linearity data shows concentration interval of studied fluoroquinolones in which the intensity of the detector response is proportional to the concentration of the analyzed substance. The DL and QL

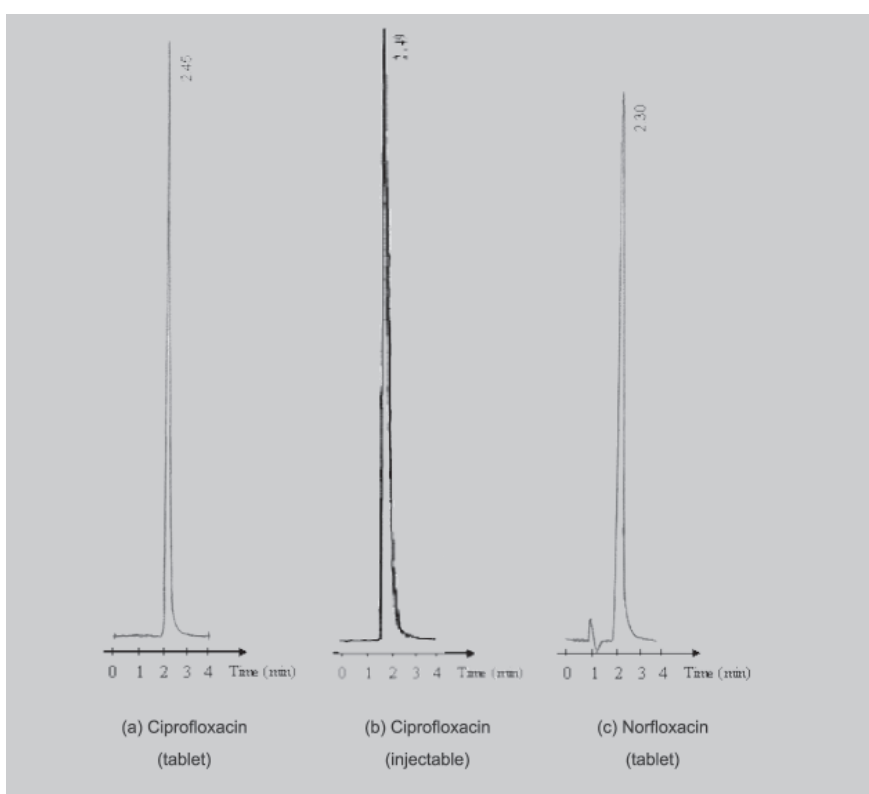

FIGURE 2 - Chromatograms of samples: (a) ciprofloxacin tablet, (b) ciprofloxacin injectable and (c) norfloxacin (15.0 $\mu \mathrm{g} / \mathrm{mL})$. Conditions: LiChrospher ${ }^{\circledR} \mathrm{RP}-18$ column $(5 \mu \mathrm{m}$, $125 \times 4 \mathrm{~mm}$ ) in LiChroCART $^{\circledR}$, mobile phase $\mathrm{H}_{2} \mathrm{O}: \mathrm{MeCN}: \mathrm{TEA}(80: 20: 0,3 \mathrm{v} / \mathrm{v}), \mathrm{pH}$ adjusted to 3.3 with phosphoric acid, flow rate $1.0 \mathrm{~mL} / \mathrm{min}, \mathrm{UV}$ detection at 279 $\mathrm{nm}$ and ambient temperature $\left(24 \pm 2{ }^{\circ} \mathrm{C}\right)$.

of CIP and NOR were $0.16,0.50$ and $0.28,0.86 \mu \mathrm{g} / \mathrm{mL}$, respectively. Table 2 shows the statistical parameters of CIP and NOR analyzed by the proposed method.

TABLE II - Statistical results of linear regression analysis in the determination of CIP and NOR by proposed method

\begin{tabular}{lcc}
\hline Statistical parameters & CIP & NOR \\
\hline Slope of curve $(\mathrm{a})$ & 2683.67 & 2824.41 \\
Intercept of curve $(\mathrm{b})$ & -621.93 & -1238.84 \\
Standard error of estimative $\left(\mathrm{S}_{\mathrm{e}}\right)$ & 165.64 & 537.46 \\
Standard error of slope $\left(\mathrm{S}_{\mathrm{b}}\right)$ & 9.89 & 32.12 \\
Standard error of intercept $\left(\mathrm{S}_{\mathrm{a}}\right)$ & 154.20 & 500.35 \\
Linear correlation coefficient $(\mathrm{r})$ & 0.9999 & 0.9999 \\
Injection levels $(\mathrm{n})$ & 3 & 3 \\
\hline
\end{tabular}

The standard deviation amongst replicate responses and relative standard deviation values (RSD) were less than $1.0 \%$, indicating precision of the method. The statistical data results obtained in the analysis of commercially available samples are shown in Table 3. The recovery values obtained were between 97.92 and $103.95 \%$, confirming accuracy of the proposed method. The percentage of recovery results are presented in Table 4 . 
TABLE III - Statistical data obtained in the analysis of samples using the proposed method

\begin{tabular}{lccccr}
\hline $\begin{array}{l}\text { Sample number } \\
\text { (Drug) }\end{array}$ & $\begin{array}{c}\text { Declared theoretical } \\
\text { concentration }(\mu \mathrm{g} / \mathrm{mL})\end{array}$ & $\begin{array}{c}\text { Found experimental } \\
\text { concentration }(\mu \mathrm{g} / \mathrm{mL})^{*}\end{array}$ & $\mathrm{SD}^{*}$ & $\mathrm{RSD}(\%)$ & $\begin{array}{c}\text { Content }(\%) \\
\text { Confidence interval** }\end{array}$ \\
\hline $1(\mathrm{CIP})$ & 15.00 & 15.51 & 0.08 & 0.51 & $103.38 \pm 0.06$ \\
$2(\mathrm{CIP})$ & 15.00 & 16.05 & 0.13 & 0.78 & $107.01 \pm 0.09$ \\
$3(\mathrm{CIP})$ & 15.00 & 15.06 & 0.08 & 0.51 & $100.43 \pm 0.06$ \\
$4(\mathrm{NOR})$ & 15.00 & 14.94 & 0.06 & 0.40 & $99.59 \pm 0.04$ \\
$5(\mathrm{NOR})$ & 15.00 & 14.91 & 0.11 & 0.74 & $99.41 \pm 0.08$ \\
\hline
\end{tabular}

(*) Average of ten determinations $(* *) 95.0 \%$ confidence level

TABLE IV - Recovery data of standard solutions added to the samples analyzed by using the proposed HPLC method

\begin{tabular}{lcccc}
\hline $\begin{array}{l}\text { Sample } \\
\text { number } \\
\text { (Drug) }\end{array}$ & $\begin{array}{c}\text { Amount } \\
\text { added } \\
(\mu \mathrm{g} / \mathrm{mL})\end{array}$ & $\begin{array}{c}\text { Amount } \\
\text { found } \\
(\mu \mathrm{g} / \mathrm{mL})\end{array}$ & $\begin{array}{c}\text { Recovery } \\
(\%)\end{array}$ & $\begin{array}{c}\text { Mean } \\
\text { Recovery } \\
(\%)\end{array}$ \\
\hline $1(\mathrm{CIP})$ & 12.0 & 12.34 & 103.29 & \\
& 14.0 & 14.20 & 100.77 & 102.22 \\
& 16.0 & 16.40 & 102.60 & \\
$2(\mathrm{CIP})$ & 12.0 & 11.95 & 101.49 & \\
& 14.0 & 14.06 & 102.44 & 101.40 \\
& 16.0 & 15.89 & 100.27 & \\
$3(\mathrm{CIP})$ & 12.0 & 12.23 & 102.69 & \\
& 14.0 & 14.14 & 100.91 & 100.51 \\
& 16.0 & 15.86 & 97.92 & \\
$4(\mathrm{NOR})$ & 12.0 & 12.19 & 102.57 & \\
& 14.0 & 14.09 & 100.67 & 102.40 \\
& 16.0 & 16.43 & 103.95 & \\
$5(\mathrm{NOR})$ & 12.0 & 12.06 & 102.72 & \\
& 14.0 & 14.10 & 102.56 & 102.72 \\
& 16.0 & 16.18 & 102.87 & \\
\hline
\end{tabular}

(a) Average of three determinations

There was minor delay in the retention time when $\mathrm{pH}$ of the mobile phase varies in 0.5 units. Practically no effect was observed when mobile phase components were intentionally deviated. Changes as much as $5 \mathrm{~mL}$ of each component in the mobile phase were altered. Consequently, due to this observation, the robustness of the method can be confirmed.

\section{CONCLUSION}

The proposed HPLC method enables quantitative determination of second generation quinolones such as CIP and NOR in pharmaceutical formulations. UV detection at $279 \mathrm{~nm}$ was found to be suitable without any interference from tablets or injectable solution excipients or solvents. The calibration curves were found to be linear with correlation coefficients above 0.9999 . The relative standard deviations values were less than $1.0 \%$. Analytical results of samples were in accordance with those of standard solution in the same concentrations. Preparation of samples is easy and efficient. The proposed HPLC method is fast, precise, accurate, sensitive, and efficient and can be used in routine analysis in quality control laboratories.

\section{ACKNOWLEDGEMENT}

The authors gratefully thank "Coordenação de Aperfeiçoamento de Pessoal de Nível Superior (CAPES)".

\section{RESUMO}

\section{Determinação quantitativa do ciprofloxacino e do norfloxacino em preparações farmacêuticas por cromatografia líquida de alta eficiência}

O objetivo desta pesquisa foi desenvolver e validar um método analítico para a determinação quantitativa do ciprofloxacino (CIP) e do norfloxacino (NOR) em preparações farmacêuticas. Um método cromatográfico simples e rápido foi desenvolvido e validado para a determinação quantitativa de dois antibióticos fluoroquinolônicos em comprimidos e injetáveis. As quinolonas foram analisadas empregando-se uma coluna RP-18, LiChrospher $^{\circledR} 100$ (125 $\left.44 \mathrm{~mm}, 5 \mu \mathrm{m}\right)$ e fase móvel constituída por água:acetonitrila:trietilamina (80:20:0.3 v/v/ v). $O \mathrm{pH}$ da mistura final foi ajustado a $3,3 \mathrm{com}$ ácido fosfórico. A vazão da fase móvel foi de 1,0 $\mathrm{mL} / \mathrm{min}$ e a detecção em UV a $279 \mathrm{~nm}$. As análises foram realizadas à temperatura ambiente $\left(24 \pm 2{ }^{\circ} \mathrm{C}\right)$. O CIP e o NOR eluíram em menos de $5 \mathrm{~min}$. As curvas de calibração foram lineares $(r>0.9999)$ na faixa de concentração entre 4,0 e 24,0 $\mu \mathrm{g} / \mathrm{mL}$. O desvio padrão relativo ( $R S D$ ) foi $<1,0 \%$ e a recuperação média foi de $101,85 \%$.

UNITERMOS: Ciprofloxacino. Norfloxacino. Preparações farmacêuticas. CLAE. 


\section{REFERENCES}

ARTESEROS, J.A.H.; BARBOSA, J.; COMPANO, R.; PRAT, M.D. Analysis of quinolone residues in edible animal products. J. Chromatogr. A, Amsterdam, v.945, p.1-24, 2002.

ASSOCIATION OF OFFICIAL ANALYTICAL CHEMISTS INTERNATIONAL. Official methods of analysis of AOAC International. 17 ed. Gaithersburg: AOAC, 2002. v.1, p.xx.

BARBOSA, J.; BERGES, R; SANZ-NEBOT, V. Solvatochromic parameter values and $\mathrm{pH}$ in aqueousorganic mixture and use in liquid chromatography. Prediction of retention of series of quinolones. $J$. Chromatogr., A, Amsterdam, v.719, p.27-36, 1996.

BELAL, F.; AL-MAJED, A.A.; AL-OBAID, A.M. Methods of analysis of 4-quinolone antibacterials. Talanta, Amsterdam, v.50, n.4. p.765-786, 1999.

BERTINO, J.; FISH, D. Safety profiles of the fluoroquinolones. Clin. Ther, Hillsborough, v.22, p.798-817, 2000.

BHOWAL, S.K.; DAS, T.K. Spectrophotometric determination of same recently introduced antibacterial drugs using ferric chloride. Anal. Lett., New York, v.24, p.25-37, 1991 .

BRITISH pharmacopoeia 1999. London: Her Majesty's Stationery Office, 1999. p.369-370, 1034-1035.

BUDVARI-BARANY, Z.S.; SZASZ, G.Y.; TAKACSNOVAK, K.; HERMECZ, I.; LORE, A. The $\mathrm{pH}$ influence on the HPLC-retention of chemotherapeutic fluorquinolone derivatives. J. Liq. Chromatogr., New York, v.14, p.3411-3424, 1991.

CHOWDARY, K.P.R.; RAO, G.D. Spectrophotometric method for the determination of lomefloxacino hydrochroride. Indian Drugs, Mumbai, v.34, p.107-108, 1997.

CORDOBA-BORREGO, M.; CORDOBA-DIAZ, M.; CORDOBA-DIAZ, D. Validation of high-performance liquid chromatographic method for the determination of norfloxacin and its application to stability studies (photostability study of norfloxacin). J. Pharm. Biomed. Anal., Amsterdam, v.18, p.919-926, 1999.
FIERENS C.; HILLAERT. S.; VAN DEN BOSSCHE W. The qualitative and quantitative determination of quinolones of first and second generation by capillary electrophoresis. J. Pharm. Biomed. Anal., Amsterdam, v.22, p.763-772, 2000.

FLURER, C.L. Analysis of antibiotics by capillary electrophoresis. Electrophoresis, Weinheim, v.18, p.2427-2437, 1997.

FRATINI, L.; SCHAPOVAL, E.E.S. Ciprofloxacin determination by visible light spectrophotometry using iron(III) nitrate. Int. J. Pharm., Amsterdam, v.127, p.279$282,1996$.

HARRIS, D.C. Métodos de calibração. In: . Análise química quantitativa. 5.ed. Rio de Janeiro: Livros Técnicos e Científicos, 2001. p.81-95.

HUSAIN, S.; KHALID, S.; NAGARAJU, V.; RAO, R.N. High-performance liquid chromatographic separation and determination of small amounts of process impurities of ciprofloxacin in bulk drugs formulations. J. Chromatogr., A, Amsterdam, v.705, p.380-384, 1995.

JOSHI, S. HPLC separation of antibiotics present in formulated and unformulated samples. J. Pharm. Biomed. Anal., Amsterdam, v.28, p.795-809, 2002.

KIRKLAND, K.M.; MCCOMBS, D.A.; KIRKLAND, J.J. Rapid, high-resolution high-performance liquid chromatography of antibiotics. J. Chromatogr., A, Amsterdam, v.660, p.327-337, 1994.

LACROIX, P.M.; CURRAN, N.M.; SEARS, R.W. Highpressure liquid chromatographic methods for ciprofloxacin hydrochloride and related compounds in raw materials. $J$. Pharm. Biomed. Anal., Amsterdam, v.14, p.641-654, 1996.

LEITE, F. Validação em análise química. 4.ed. São Paulo: Átomo, 2002.p.69-72.

LORIAN, V. Antibiotics in Laboratory Medicine. 4.ed. Baltimore: Williams \& Wilkins, 1996. p. 591-592.

MANDEL, G.I.; PETRI JUNIOR, W.A. Antimicrobial agents: sulfonamides, trimethoprim-sulfamethoxazole, quinolones, and agents for tract infections. In: Goodman \& Gilman's: The pharmacological basis of therapeutics. 9. ed. New York: Mcgraw-Hill, 1996. p. 1065-1068. 
MARZO, A.; DAL BO, L. Chromatography as an analytical tool for selected antibiotic classes: a reappraisal addressed to pharmacokinetic applications. J. Chromatogr. A, Amsterdam, v.812, p.17-34, 2002.

MAZUEL, C. Norfloxacin. Anal. Profiles Drug Subst. Excipients, San Diego, v.20, p.557-600, 1991.

MORLEY, J.A.; EROLD Jr., L. Determination of fluorquinolne antibacterial as N-Acyl derivatives. Chromatographia, Wiesbaden, v.37, p.295-299, 1993.

SAMANIDOU, V.F.; CHRISTODOULOU, E.A.; PAPADOYANNIS, I.N. Determination of fluoroquinolones in edible animal tissue samples by high performance liquid chromatography after solid phase extraction. J. Sep. Sci., Weinheim, v. 28, p. 555-565, 2005.

SAMANIDOU, V.F.; DEMETRIOU, C.E.; PAPADOYANNIS, I.N. Direct determination of four fluoroquinolones, enoxacin, norfloxacin, ofloxacin, and ciprofloxacin, in pharmaceuticals and blood serum by HPLC. Anal. Bioanal. Chem., Heidelberg, v.375, p.623629, 2003.

SOWINSKI, K.M.; KAYS, M.B. Determination of ciprofloxacin concentrations in human serum and urine by HPLC with ultraviolet and fluorescence detection. J. Clin. Pharm. Ther., Oxon, v. 29, p. 381-387, 2004.
SUN, S.-W.; CHEN, L.-Y. Optimization of capillary electrophoretic separation of quinolones antibacterials using the overlapping resolution mapping scheme. $J$. Chromatogr., A, Amsterdam, v.766, p.215-224, 1997.

THOPPIL, S.O.; AMIN, P.D. Stability indicating reversedphase liquid chromatographic determination of ciprofloxacin as bulk drug and in pharmacetical formulations. J. Pharm. Biomed. Anal., Amsterdam, v.22, p.699-703, 2000.

TIEFENBACHER, E.M.; HAEN, E.; PRZYBILLA, B.; KURZ, H. Photodegradation of some quinolones used as antimicrobial therapeutics. J. Pharm. Biomed. Anal., Amsterdam, v.83, p.463-467, 1994.

TORNIAINEN, K.; TAMMILEHTO, S.; ULVI, V. The effect of $\mathrm{pH}$, buffer type and drug concentration on the photodegradation of ciprofloxacin. Int. J. Pharm., Amsterdam, v.132, p.53-61, 1996.

UNITED States Pharmacopeia. 27.ed. Rockville: United States Pharmacopeial Convention, 2004. p.454-457, 13421343.

VYBIRALOVA, Z.; NOBILIS, M.; ZOULOVA, J.; KVETINA, J.; PETR, P. High-performance liquid chromatographic determination of ciprofloxacin in plasma samples. J. Pharm. Biomed. Anal., Oxford, v. 37, p. 851$858,2005$.

Recebido para publicação em 17 de dezembro de 2004. Aceito para publicação em 18 de agosto de 2005. 